\title{
ETHNO-CULTURAL COMPETENCE AS A COMPONENT OF COMPETENCE IN COMMUNICATION
}

\author{
Tatiana G. Stefanenko \\ Lomonosov Moscow State University \\ Moscow \\ Aleksandra S. Kupavskaya \\ LITE-College \\ London
}

\begin{abstract}
The importance of success in cross-cultural communication in the modern world is growing every day. However, because of the lack of a coherent methodological framework and common terminology, there is eclecticism in the practical concepts of successful intercultural communication. This article presents the integration of Russian and western social-psychological knowledge and creates a model of the ethno-cultural competence. Thus, in accordance with Russian social psychology, the socio-perceptive, communicative and interactive aspects of ethno-cultural communication are allocated and described. The three-part model of ethno-cultural competence, which includes cognitive, behavioral and motivational factors, was operationalized in order to become a base for standardized training programs to increase ethnic and cultural competence.

Keywords: ethno-cultural competence, intercultural communication, social-perceptive, communicative and interactive components of ethno-cultural competence, competency model of ethno-cultural communication.
\end{abstract}

At the beginning of the 21 st century the world community was faced with the fact that in societies of different countries and continents, along with the trend of globalization, emerged the aspirations to preserve their identity, the importance of ethnic identity manifested is growing. Unfortunately, such a clash of contradicting interests entails the growth of ethnic tensions that lead to open confrontation, conflicts and even wars.

This issue is particularly relevant for today's multicultural Russia. Russian ethno-psychology has only a thirty-year history and, at the same time, centuries-old baggage of unresolved issues for today. It is facing many urgent tasks, which concerns harmonious interaction between dif- 
Ethno-Cultural Competence as a Component of Competence in Communication 551

ferent cultures in this multicultural society. Owing to that, one of the most important problems is the development of ethno-cultural competence of Russian citizens.

The popularity of current issue in modern science must be recognized. There is experience of foreign (Bennett, 1995; Berry et al., 2002; Stephan \& Stephan, 2001; Ting-Toomey, 1999; Ward, Bochner, \& Furnham, 2001) and Russian (Ageev, 1983; Lebedeva, 1999; Lebedeva, Luneva, Stefanenko, \& Martynova, 2003; Soldatova, 1998; Stefanenko, 2009; Huhlaev, 2007) researchers. However, because of the lack of a coherent methodological framework and common terminology, there is eclecticism in the practical concepts of successful intercultural communication. This article is an attempt to correlate the modern concepts of crosscultural communication with the interpretation of the phenomenon of communication in a Russian's social psychology, which consists of three sides: social-perceptive, communicative and interactive.

Defining a clear methodological basis for the study of ethno-cultural competence is also relevant because of the fact that Russia is adopting ideas of the Bologna Process, which purpose is to create the higher education area by making academic degree and quality assurance standards more comparable and compatible throughout Europe. Also, the growing popularity of multicultural education, based on the concept of multilevel unity of culture and education, dictates the need for an easy-to-use conceptual apparatus and effective training programs. The variety of models and types of programs of development of ethno-cultural competence requires, firstly, their methodological rethinking within the domestic psychological paradigm (Zaitseva, 2002; Stefanenko \& Kupavskaya, 2006), and secondly, the study of their effects and opportunities (Zhukov, 2004; Vedder \& Horenczyk, 2006).

In foreign literature there are several synonymous terms for the described phenomenon, such as intercultural competence, cultural and communicative competence, cross-cultural competence, multicultural social competence. For example, D. Matsumoto defines the ability to produce an effective communication in intercultural interaction as an intercultural communicative competence (Matsumoto, 1996).

From our perspective, ethno-cultural competence is a term which most accurately reflects the meaning and essence of the described concept. It seems important to emphasize an ethno-cultural component of 
the communication, limiting the concept of "culture." It is important to bear in mind that difficulties in interaction arise not only from differences between cultures, but, as evidenced by the current situation in Russia, the different ethnic communities.

According to the fore mentioned facts, the connection between ethno-cultural competence and the concept of "communicative competence" became for us one of the key issues. We agree with Y. Kim, that intercultural competence is not simply a communicative competence in a cultural context; it is, above all, a comprehensive personal ability to cope with the effects of individuals belonging to different cultural groups and stress, associated with it (Kim, 1991). From our point of view, Y. Kim emphasizes the meaning of the ability to adapt, which, of course, exerts a strong influence on the efficiency of cross-cultural interaction, but does not exhaust all the skills and knowledge, which are necessary in order to achieve communication goals, while contacting with other cultures. However, this remark can be taken into account if we understand intercultural communication as a special case of interpersonal, to which most researchers are inclined (Matsumoto, 1996; Rot \& Kopteltseva, 2006; Stefanenko \& Kupavskaya, 2006).

In the first stage of developing the ideas about competence (in the middle of the twentieth century), many authors believed that it is based on personal characteristics, but the direct link between competence and the social context is obvious for now. There is no doubt that the most important feature of the ethno-cultural competence is its direct dependence on the social context.

Before defining this concept and operationalize it, firstly, it will be observed in terms of the widely developed and methodologically sound in Russian social psychology concept of communicative competence and, secondly, in terms of competency model.

The pace of today and the variety of possibilities of intercultural contacts require a special knowledge and culture of communication and the ability to react quickly and adequately in difficult communicative situations. Consequently, the modern person just needs to develop ethno-cultural competence, which helps to feel freely in all aspects of interpersonal communication. It seems to us that one of the important tasks of modern socio-psychological knowledge is to consider the specificity of ethno-cultural competence within the broader competence of communication and, after that, to create effective training programs on this basis. 
Ethno-Cultural Competence as a Component of Competence in Communication 553

In the Russian social psychology, communication is understood as a "way of contact (information exchange) between active individuals (interaction) seeking to achieve mutual understanding (perceive each other in a certain way)" (Solovyova, 1992, p. 63). In line with the allocation of social-perceptive, communicative and interactive aspects of communication (Andreeva, 2004), development of competence in intercultural communication can also be seen in terms of these three aspects, respectively, highlighting the development of social-perceptive, communicative and interactive components of ethno-cultural competence. It must be emphasized that the concept of "communication" is not equal to one of these selected components, as well as each component separately suggests correlation with the two others aspects (Petrovskaya, 2007).

In order to develop social-perceptive competence aspect it is needed to work with cognitive processes - stereotyping and social causal attribution. Social perception, which is primary in relation to other aspects of communication, plays a key role in developing social attitudes.

The work with attitudes and, above all, with prejudice, becomes a priority during development of an ethno-cultural competence. Phenomena of social categorization, group identification and intergroup differentiation shape our ethnic identity. It is especially important, because the positivity and completeness of ethnic identity is directly connected to the adequacy in the perception of another group. Inadequacy in intergroup perception creates ethnic intolerance, which could be defined as a "mostly negative perceptions of ethnic culture of others' and extra-positive perception of one's own" (Lebedeva, Luneva, \& Stefanenko, 2004, p. 14).

In order to achieve a high level of competence in intercultural communication a high-level of social perception skills is needed: the ability to perceive other people's behavior adequately and interpret their social reactions, feelings and intentions correctly. These skills contribute to the development of social sensitiveness, which is mainly characterized by the ability to reflect the other people's behavior, and includes such traits as empathy, social understanding, and social intelligence (Krichevsky \& Dubovskaya, 2001).

According to the concept of M. Bennett, ethno-cultural competence is directly determined by intercultural sensitivity which demands attention to the subjective experience of the learner. The key to such sensitivity and related skills in intercultural communication is the way in which learners construe cultural difference. There are six stages. Earlier stages 
of the continuum define the denial of difference, the evaluative defense against difference, and the universalist position of minimization of difference. Later stages define the acceptance of difference, adaptation to difference, and the integration of difference into one's world view (Bennett, 1986). Typically, people with bicultural or multicultural identity have been socialized in several cultures simultaneously (e.g., children from mixed marriages). The bicultural identity is most favorable for representatives of minority groups in a multiethnic society. It is shown that children with bicultural orientation have greater freedom of cognitive styles, a greater degree of creativity and adaptability (Stefanenko, 2004).

In accordance with Russian social-psychology, communication as an exchange of information (communicative component) suggests, firstly, the establishment of joint activities between the subjects of communication. It ensures the unity of activity, communication and cognition, and consequently - a joint comprehension of the subject. Secondly, the impact on partner of communication through a system of signs and, accordingly, changing the type of relations, which preceded the interaction. To this effect was carried out, thirdly, speaking a common language and, fourthly, the lack of communication barriers are needed (Andreeva, 2004).

The last two conditions are particularly important during intercultural interaction. Indeed, there are lots of communication barriers within this type of communication, especially social ones. For example, a significant barrier of intercultural communication could arise because of the lack of knowledge of the basic factors and regulators of intercultural interaction - the norms, roles, values, etc. The most straightforward way to penetrate the culture is to study the values, traditions and customs, which might be found in the folklore (tales, proverbs, sayings, etc.).

In the context of intercultural communication an important role is played by norms, which are learned during socialization and include a collective assessment of what should be the behavior of one's culture. Rules and regulations are closely linked to the performed role in the communication process - the expectations of certain behavior from the subject of the group.

The above-described regulators of behavior one can realize in the process of socialization through verbal and nonverbal influence. The ability to understand and interpret is possible only when the communicator and the recipient have a common or similar coding and decoding system (Andreeva, 2004; Matsumoto, 1996), which also is an important part of the ethno-cultural competence. 
Ethno-Cultural Competence as a Component of Competence in Communication 555

The ethnical "picture of the world," the principles of social organization, which appears as a main basis for the cultural identity, are learnt by the verbal communication. That language is often considered as the main source of the ethnic identity. The identification of people with their language is a very common belief. However, there is a lot of evidence that ethnic identity may be linked not so much with the actual use of language by all members of the ethnic group, but rather with its symbolic role as a formation of a sense of belonging to a community where the language is primarily a symbol of unity with "our" people (Dontsov, Stefanenko, \& Utalieva, 1997).

It is widely known that even before learning the native language a person learns to understand the context of nonverbal communication, which contributes to encoding and decoding verbal communications. Nonverbal communication (space, time, style and features of speech intonation, facial expressions, gestures, and others) is more than other aspects of communication influenced by culture. The ability to decode its clearly indicates a high level of ethno-cultural competence.

There is no doubt that ethno-cultural competence requires strong development of both - verbal and nonverbal communication. However, it is significant that one might be more or less important than the other in different cultures. For example, representatives of individualistic cultures prefer to be more accessible to others through verbal self-disclosure; representatives of collectivistic cultures put more emphasis on expressing themselves nonverbally (Lebedeva, 1999).

To help to reduce the social barriers of communication there is also the knowledge of different measures of cultures, which determine their specificity. Eleven major measures were allocated by W. Stephan and C. Stephan: individualism versus collectivism; tolerance for deviation, tolerance for uncertainty; masculinity versus femininity; orientation toward human nature; the extent to which humans are seen as innately good, evil, or mixed; cultural complexity; emotional control; high versus low contact; power distance; low context versus high context; personnature orientation (Stephan \& Stephan, 1996). The list can also be added with distinction of cultural orientation in time (the past, present, future), the degree of preferred activity (the desire to be, to become or to do), contrasting cultures of guilt and shame, having or not having a written language etc. In our opinion, knowledge about the different styles of communication and the ability to select the appropriate one also demonstrates a high level of ethno-cultural competence. 
It is assumed that the aspect of competence in interaction is the most important one, because it combines the capabilities of the two previous components.

Referring to this component, it is important to remember about the possibilities of contact hypothesis - the assumption that direct communication under certain conditions contribute to the improvement of social stereotypes and the destruction of prejudices. However, according to G. Allport, the hypothesis works if the interacting groups are of an equal status, share common goals, which concern with cooperation. Also it is important that these groups are following common set of rules, and that the idea of the need to contact is supported by social institutions (Allport, 1979). Developing the ideas of G. Allport, M. Hewstone singled out three aspects of contact, which can significantly affect the generalization of positive effects. Firstly, the recognition of differences in groups leads to greater differentiation in intergroup perception. Secondly, the use of information, which doesn't confirm the initial stereotype, suggests the spread of positive attitudes. Thirdly, an increase in interpersonal communication promotes understanding and acceptance not only differences but also similarities, which leads to de-categorization and personalization (Hewstone, 1996).

During the contact a person also learns to choose and create different coping strategies. Ability to implement positive coping styles helps to avoid or easily overcome the cultural shock, and in many ways appears as a key to effective intercultural interaction.

In order to implement the ideas of the contact hypothesis, to gain strategies for coping behavior and other factors in the development of ethno-cultural competence, a wide variety of methods was created. The most effective of which, in our opinion, is the training, which involves the contact and interaction of different cultures in a specially created conditions during the intercultural communication.

Methodological design of any effective training program, according to many authors, must begin with the end - with a description of the result (Luneva, 2004; Masterov, 2004; Gudykunst, Guzley, \& Hammer, 1996; Paige, 1996). It can be done effectively by using competency model. In this regard, it is important to describe an ethno-cultural communication in terms of competency model and to provide components which describe the cultural competence as a phenomenon, separating it from the components of a more general one, as it was defined above, communicating competence. 
Ethno-Cultural Competence as a Component of Competence in Communication 557

\section{Competency model}

\section{of ethno-cultural communication}

The necessity to consider the ethno-cultural competence in terms of competency models is also confirmed by numerous social and psychological needs. The first of these is related to the reformation of higher education in Russia according to the ideas of the Bologna Process. The second of these is the multiple demands of socio-psychological practice to develop effective and, at the same time, standardized, easily "passed from hand to hand" methods, that could help to reduce ethnic tensions and to develop a positive ethnic identity of Russian citizenships.

If we consider competence as an assessed characteristic, shown in action, it turns out that ethno-cultural competence might be a very subjective description. In order to prevent it, most researchers emphasize the importance of the "efficiency" and the "adequacy" criteria (Koester, Wiseman, \& Sanders, 1993). In this context the "efficiency" means achieving the goals of communication, whether the "adequacy" means the lack of significant violations of the regulations in particular cultural context, and compliance with the expectations of the opposite side.

Defining competence broadly, we can establish it as a willingness and ability to cope effectively with the challenges from social reality. This is mostly subjective characteristics described by the behavioral models, standards and criteria for effective solutions to social problems (competence). Deeper theoretical analysis suggests the differentiation of metaand core (nuclear) competencies.

Meta-competence is a universal formation, which presents a basis for creating other types of competences. The concept was developed in academic environment and was taken as some of the fundamental unit, the foundation for developing more specific ones. At the same time core (nuclear) competence is defined by the solidity and breadth of application (Zhukov, 2004). According to these two levels of competency model, ethno-cultural competence would be further operationalized.

There is no shortage of empirical studies, which are trying to determine the factors of the effectiveness during multicultural contacts in today's cross-cultural psychology. For instance, a number of works was summarized by B. Spitzberg, which let the researcher identify empirically more than fifty factors of intercultural competence (Spitzberg, 1997). These factors were analyzed in terms of competence model, regarding 
ethno-cultural competence as a core-competence and communication one as a meta-competence, as long as the first mentioned one is based and formatted on the second one.

Thus, analyzing the list of proposed factors as determined intercultural communication, we have chosen the ones that contribute to the development of communicative competence and, therefore, constitute meta-competence of intercultural communication:

Ability to deal with psychological stress

Ability to establish interpersonal relationships

Ability to facilitate communication

Ability to understand others

Adaptiveness

Charisma

Cooperation

Familiarity in interpersonal relations

General competence as teacher (task)

Interpersonally sensitive maturity

Self-actualizing search for identity

Self-confidence / Initiative and Self-consciousness

Self-disclosure

Verbal behaviors

Etc.

Following the Spitzberg's list (Spitzberg, 1997, p. 381), a core-competence might be determined by:

Ability to adjust to different cultures

Awareness of self and culture

Cultural differentiation

Cultural empathy

Cultural interaction

Non-ethnocentrism

The list of factors also needs to be added by the linguistic competence and level of knowledge of local culture (Almazova, 2003; Matsumoto, 1996; Ter-Minasova, 2004).

To summarize, the above characteristics represent a list of empirically derived factors of intercultural competence. Our basic objective is 
Ethno-Cultural Competence as a Component of Competence in Communication 559

to separate the levels of competencies in order to highlight specific characteristics for ethno-cultural competence, and its subsequent determination. Our next step is to analyze them in terms of knowledge, skills and behavior, which directly affect the competence.

\section{Models of ethno-cultural competence}

Considering ethno-cultural competence as a component of competence in communication, allocating its three components, analyzing the phenomenon from the perspective of competency model, helps us to define the concept. It is important to include in this concept all three components of communication, and motivation for building relationships with representatives of other cultures successfully. All of this allows us to identify ethno-cultural competence as the sum of knowledge about one's and others' cultures, which could be seen through the attitudes and behavior in order to ensure effective interaction with representatives of these cultures.

In order to summarize the phenomenon, we would perform the existing models of intercultural competence and present our vision of it.

W. Gudikunst proposes the following model of intercultural competence: motivational factors (the needs of the participants of intercultural communication, social norms, self-images, and openness to new information), knowledge factors (expectations, perceptions of more than one point of view, which could occur during the cross-cultural contact, knowledge of alternative interpretations and knowledge of cultural similarities and differences) and skills factors (the ability to show empathy, tolerance to ambiguity and uncertainty, adaptability in communication, the ability to modify behavior and create new categories) (Gudikunst \& Ting-Toomey, 1990).

Model of M. Hammer and H. Nishida is also the three-part model. In their view, intercultural competence has three levels: understanding situations and behavior caused by specific rules, the understanding of other cultures in general, emotional attitude towards another culture (Hammer \& Nishida, 1996).

According to D. Matsumoto, the basic components of intercultural competence are the thoughtfulness and the ability to control emotions, primarily negative ones (Matsumoto, 1996). 
Thus, these models show the four main factors of ethno-cultural competence: cognitive, motivational, behavioral and emotional. However, taking into consideration the close connection between motives and emotions, the selection of the last component seems superfluous.

Generalizing and systematizing the components, which were mentioned above (excluding those that relate to meta-competence), we propose the following model of ethno-cultural competence, consisting of three factors - cognitive, behavioral and motivational:

\begin{tabular}{|c|l|}
\hline Factor & \multicolumn{1}{|c|}{ Components of the ethno-cultural competence } \\
\hline Cognitive & $\begin{array}{l}\text { - Knowledge of one's own culture and the culture of others (tradi- } \\
\text { tions, customs, values, norms, rules, roles, etc.) } \\
\text { - Views about the similarities and differences between one's own } \\
\text { culture and culture of others } \\
\text { - Awareness of the importance of cultural differences } \\
\text { - Knowledge, that helps to interpret the behavior of different ethnic } \\
\text { groups } \\
\text { - Language competence } \\
\text { - Knowledge, that helps to provide adequate encoding and decod- } \\
\text { ing nonverbal messages from representatives of other cultures } \\
\text { - Adequate notion about the cultural distance }\end{array}$ \\
\hline Behavioral & $\begin{array}{l}\text { - Ability to adapt behavior for different cultures } \\
\text { - Skills that contribute in presenting an adequate non-verbal reac- } \\
\text { tions in foreign culture } \\
\text { - The ability to control emotional feelings, associated with differ- } \\
\text { ences in cultures } \\
\text { - Ability to adjust the level of anxiety in intercultural interaction }\end{array}$ \\
\hline Motivational & $\begin{array}{l}\text { - The necessity of intercultural communication } \\
\text { - Willingness to show empathy to the people from other cultures } \\
\text { - Willingness to engage into cross-cultural interaction } \\
\text { - Willingness to follow the norms and rules of behavior, which exist } \\
\text { in other cultures } \\
\text { - The need to obtain knowledge about the people from the other } \\
\text { culture } \\
\text { - High level of attraction to the representatives of other cultures } \\
\text { - Willingness to collaborate, based on the position of ethnic and } \\
\text { cultural universalism }\end{array}$ \\
\hline
\end{tabular}

In order to achieve ethno-cultural competence, the individual must acquire and develop skills in each of these areas. 
Ethno-Cultural Competence as a Component of Competence in Communication 561

In addition, it is important to remember that meta-competence of an ethno-cultural one is a competence in communication. This means that its development will have a significant impact on the previously described one. For instance, in scientific literature, factors such as the attitude to pluralism, tolerance to high levels of uncertainty, flexibility of thinking (e.g., ability to create new categories) and behavior (e.g., choice of behavioral responses), ability to decentralize, openness to new experience, etc., are often cited.

\section{Conclusion}

Thus, in accordance with Russian social psychology, the socio-perceptive, communicative and interactive aspects of ethno-cultural communication were allocated and described. Ethno-cultural competence, being one of the aspects of competence in communication, contributes a lot to the formation of an attitude of tolerance, improving inter-ethnic dialogue in modern Russia and the whole world.

Since the improvement of intercultural communication is one of the areas where the growth of psychological knowledge through awareness is not enough, we see the future development of ethno-cultural competency via training methods, which gives the ability to integrate knowledge and practical experience. The introduced model, which consists of pooling western and Russian social psychology knowledge, helps to develop this kind of training programs. This model allows, firstly, to set goals and to describe the result of intercultural learning in terms of skills, and secondly, to establish standardized training programs to increase ethnic and cultural competence, and, thirdly, to move towards measuring the effectiveness of different models of learning.

\section{References}

Ageev, V.S. (1983). Psihologiâ mežgruppovyh otnošenij [Psychology of Intergroup Relations]. Moscow: MGU.

Allport, G. (1979). The Nature of Prejudice. New York: Basic Books.

Almazova, N.I. (2003). Kross-kul'turnâ̂ sostavlâûsââ inovacionnoj kommunikacii: kognitivnyj $i$ didaktičeskij aspekty [Cross-Cultural Component of Foreign Language Communication: Cognitive and Didactic Aspects]. Saint Petersburg: Nauka. 
Andreeva, G.M. (2004). Social'naâ psihologiâ [Social Psychology]. Moscow: Aspekt Press.

Bennett, M.J. (1986). A Developmental Approach to Training for Intercultural Sensitivity. International Journal of Intercultural Relations, 10 (2), 179-196.

Bennett, M.J. (1995). Critical Incidents in an Intercultural Conflict-Resolution Exercise. In S.M. Fowler \& M.G. Mumford (Eds.), Intercultural Sourcebook: Cross-Cultural Training Methods (Vol. 1, pp. 147-156). Yarmouth (ME): Intercultural Press.

Berry, J.W., Poortinga, Y.H., Segall, M.H., \& Dasen, P.R. (2002). Cross-Cultural Psychology: Research and Applications. Cambridge, etc.: Cambridge University Press.

Dontsov, A., Stefanenko, T., \& Utalieva, J. (1997). Âzyk kak faktor ètničeskoj identičnosti [Language as a Factor of Ethnic Identity]. Voprosi psihologii, 4, 75-86.

Gudykunst, W.B., \& Ting-Toomey, S. (1990). Culture and Interpersonal Communication. In Sage Series in Interpersonal Communication. Vol. 8. Newbury Park.

Gudykunst, W.B., Guzley, R.M., \& Hammer, M.R. (1996). Designing Intercultural Training. In Handbook of intercultural training (pp. 61-80). Thousand Oaks, CA: Sage.

Hammer, M.R., \& Nishida, H. (1996). The Influence of Situational Prototypes on Dimensions of Intercultural Communication Competence. Journal of Cross-Cultural Psychology, 27 (3), 213-229.

Hewstone, M. (1996). Contact and Categorization: Social Psychological Interventions to Change Intergroup Relations. In C.N. Macrae, C. Stantor, \& M. Hewstone (Eds.), Stereotypes and Stereotyping (pp. 323-360). New York, London: Guilford Press.

Huhlaev, O.E. (2007). Pričiny ètničeskogo konflikta: postroenie social'no-filosofskoj tipologii [The Causes of Ethnic Conflicts: The Construction of Socio-Psychological Typology] http://www.etnopsy.ru/txt.htm. Retrieved December 11, 2007.

Kim, Y.Y. (1991). Intercultural Communication Competence: A Systems-Theoretic View. In S. Ting-Toomey \& F. Korzenny (Eds.), Cross-Cultural Interpersonal Communication (pp. 213-229). Thousand Oaks, CA: Sage.

Koester, J., Wiseman, R.L., \& Sanders, J.A. (1993). Multiple Perspectives of Intercultural Communication Competence. In J. Koester \& R.L. Wiseman (Eds.), Intercultural Communication Competence (pp. 3-15). Newbury Park, CA: Sage.

Krichevsky, R., \& Dubovskyaya, E. (2001). Socialnaâ psihologiâ maloj gruppy [Social Psychology of Small Group]. Moscow: Aspekt Press.

Lebedeva, N.M, Luneva, O.V., \& Stefanenko, T.G. (2004). Trening ètničeskoj tolerantnosti dlâ škol'nikov [Training of Ethnic Tolerance for Students]. Moscow: Privet.

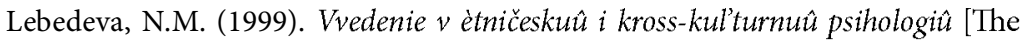
Introduction to Ethnic and Cross-Cultural Psychology]. Moscow: Klûč.

Lebedeva, N.M., Luneva, O.V., Stefanenko, T.G., \& Martynova, M.Y. (2003). Mežkul'turnyj dialog: trening ètno-kul'turnoj kompetentnosti [Intercultural Dialogue: Training of Ethno-Cultural Competency]. Moscow: RUDN. 
Luneva, O.V. (2004). Metodičeskie osnovy psihologičeskogo treninga v škole [Methodical Principles of Psychological Training in School]. In N.M. Lebedeva, T.G. Stefanenko, \& O.V. Luneva, Mežkul'turnyj dialog v škole. Kniga 1: Teoriâ i metodologiâ [Intercultural Dialogue in the School. Book 1: Theory and Methodology] (pp. 119-148). Moscow: RUDN.

Masterov, B.M. (2004). Konstruirovanie treningovyh procedur: Tehnologiâ i tvorčestvo [Training Design: Technology and Creativity]. In Y.M. Zhukov (Ed.), Metody praktičeskoj socialnoj psihologii: diagnostika, konsul'tirovanie, trening [Methods of Practical Social Psychology: Assessment, Counseling, Training] (pp. 152-185). Moscow: Aspekt Press.

Matsumoto, D. (1996). Culture and Psychology. Pacific Grove, CA, etc.: Brooks/Cole Publishing Company.

Paige, R.M. (1996). Intercultural Trainer Competencies. In Handbook of intercultural training (pp. 148-165). Thousand Oaks, CA: Sage.

Petrovskaya, L.A. (2007). Obŝenie - kompetentnost' - trening [Communication Competence - Training]. Moscow: Smysl.

Rot, J., \& Kopteltseva, G. (2006). Mežkul'turnaâ kommunikaciâ: teoriâ, trening [Intercultural Communication: Theory, Training]. Moscow: Uniti-Dana.

Soldatova, G.U. (1998). Psihologiâ mežètničeskoj naprâžennosti [Psychology of Inter-Ethnic Tensions]. Moscow: Smysl.

Solovyova, O.V. (2002). Obŝenie: tradicionnye issledovaniâ i novaâ problematika [Communication: Traditional Research and New Perspectives]. In G.M. Andreeva \& A.I. Dontsov (Eds.), Socialnaâ psihologiâ v sovremennom mire [Social Psychology in the Modern World] (pp. 61-75). Moscow: Aspekt Press.

Spitzberg, B.H. (1997). A Model of Intercultural Communication Competence. In L.A. Samovar \& R. Porter (Eds.), Intercultural Communication: A Reader (pp. 379-391). Belmont, Albany, Bonn, etc.: Wadsworth Publishing Company.

Stefanenko T.G. (2009). Etnopsihologija [Ethnopsychology]. Moscow: Aspekt Press.

Stefanenko, T.G. (2004). Stanovlenie ètničeskoj identičnosti u detej i podrostkov [The Formation of Children's and Adolescents' Ethnic Identity]. In N.M. Lebedeva, T.G. Stefanenko, \& O.V. Lunyova, Mežkul'turnyj dialog v škole. Kniga 1: Teoriâ $i$ metodologiâ [Intercultural Dialogue in the School. Book 1: Theory and Methodology] (pp. 8-56). Moscow: RUDN.

Stefanenko, T.G., \& Kupavskaya, A.S. (2006). Trening kak metod razvitiâ ètnokul'turnoj kompetentnosti [Training as a Method of Developing Ethno-Cultural Competency]. In T.G. Stefanenko, Ėtnopsihologiâ. Praktikum [Ethno-Psychology: Workshop]. Moscow: Aspekt Press.

Stephan, W.G., \& Stephan, C.W. (1996). Intergroup Relations. Madison: Brown \& Benchmark. 
Stephan, W.G., \& Stephan, C.W. (2001). Improving Intergroup Relations. Thousand Oaks, CA: Sage.

Ter-Minasova, S.G. (2004). Âzyk i mežkul'turnâ̂ kommunikaciâ [Language and Intercultural Communication]. Moscow: MGU.

Ting-Toomey, S. (1999). Communication across Cultures. New York: The Guilford Press.

Vedder, P., \& Horenczyk, G. (2006). Acculturation and the School. In D.L. Sam \& J.W. Berry (Eds.), The Cambridge Handbook of Acculturation Psychology (pp. 419-438). Cambridge, etc.: Cambridge University Press.

Ward, C., Bochner, S., \& Furnham, A. (2001). The Psychology of Cultural Shock. London, New York: Routledge.

Zaitseva, T. (2002). Teoriâ psihologičeskogo treninga [Theory of Psychological Training]. Moscow: Smysl.

Zhukov, Yu.M. (2004). Kommunikativnyj trening [Training of Communication]. Moscow: Gardariki. 